\title{
Partition of planktonic respiratory carbon requirements during a phytoplankton spring bloom
}

\author{
Roswati Md Amin ${ }^{1,2,5, *}$, Ulf Båmstedt ${ }^{1,2}$, Jens C. Nejstgaard ${ }^{3,6}$, Iole Di Capua ${ }^{4}$ \\ ${ }^{1}$ Umeå Marine Sciences Centre, Umeå University, Norrbyn 91020 Hörnefors, Sweden \\ ${ }^{2}$ Department of Ecology and Environmental Sciences, Umeå University, 90187 Umeå, Sweden \\ ${ }^{3}$ Uni Research, Thormøhlensgate 49, 5006 Bergen, Norway \\ ${ }^{4}$ Ecology and Evolution of Plankton, Stazione Zoologica 'A. Dohrn', Villa Comunale, 80121 Napoli, Italy \\ ${ }^{5}$ Present address: Department of Marine Science, Faculty of Maritime Studies and Marine Science, \\ Universiti Malaysia Terengganu, 21030 Terengganu, Malaysia \\ ${ }^{6}$ Present address: Skidaway Institute of Oceanography, 10 Ocean Science Circle, 31411 Savannah, Georgia, USA
}

\begin{abstract}
We studied the effect of variable phytoplankton biomass and dominance of the diatom Skeletonema marinoi on the planktonic community respiratory carbon requirement over a period of $14 \mathrm{~d}$ (14 to 28 April 2008) in 3 different mesocosms filled with natural water at Espegrend marine biological field station in Raunefjord, Norway. The carbon requirement was measured on mesozooplankton (the calanoid copepod Calanus finmarchicus) and 3 other size fractions of plankton $-<200 \mu \mathrm{m}$ (dominated by microzooplankton), $<15 \mu \mathrm{m}$ (dominated by nanoplankton including most of the phytoplankton) and particles passing GF/C filters (dominated by bacterioplankton) by measuring oxygen consumption using an optode system with 2 SensorDish Readers. The respiratory carbon requirement showed no clear trend over time for any of the 4 groups. The mesozooplankton contributed the least to the total community carbon requirement, corresponding to $<6 \%$ of primary production. In contrast, microzooplankton and nanoplankton consistently dominated the community carbon requirement, corresponding to $>50 \%$ of the primary production, while bacterioplankton showed an intermediate and variable contribution (ca. $<20 \%$ with a maximum of $50 \%$ ). Feeding experiments on mesozooplankton (C. finmarchicus) $2 \mathrm{~d}$ before the peak in phytoplankton biomass showed that the copepods ingested from 2.4 to 4.3 times their respiratory carbon requirements, thus providing a high potential for growth. Respiratory carbon requirements of mesozooplankton were not significantly related to dominance or quantity of food available, whereas the respiratory carbon requirements of other groups were all related to the production of 22:6(n-3) fatty acid. The present study confirms the important role of microorganisms in the biological carbon transformation through the food web during a phytoplankton spring bloom.
\end{abstract}

KEY WORDS: Plankton community - Respiratory carbon requirement - Energy transfer · Skeletonema marinoi · Mesozooplankton · Calanus

Resale or republication not permitted without written consent of the publisher

\section{INTRODUCTION}

Planktonic community respiration represents the baseline in estimating energy flow in marine ecosystems (Hernández-León \& Ikeda 2005). A differentiation of community respiration into different trophic levels provides a fundamental key from which the trophic structure can be quantified in terms of transfer and partitioning of primary production from pro- ducers and losses associated with respiration of all organisms (Kemp \& Boynton 2004). In spite of the great potential of community respiration partitioning in studies of community structure and carbon trophic transfer, there are very few data directly apportioning community respiration to trophic group (reviewed by Robinson et al. 2002a). Some studies suggest that bacterioplankton dominate community respiration (e.g. Jensen et al. 1990, Blight et al. 1995, 
Rivkin \& Legendre 2001), whereas others suggest that bacterioplankton represent less (Ducklow et al. 2000) and that algal respiration (Lancelot et al. 1991) and microzooplankton (Calbet \& Landry 2004) account for the bulk of community respiration in some eutrophic ecosystems. Consequently, the balance between photosynthesis and respiration will be strongly influenced by the quantitative relationships between microzooplankton, phytoplankton and bacterioplankton.

Mesozooplankton respiration rate is an estimation of their minimum energetic requirements under given conditions, in terms of carbon (HernándezLeón \& Gómez 1996), thus representing the amount of energy necessary to maintain the structure and activity at this trophic level (Alcaraz \& Packard 1989). Mesozooplankton is generally assumed to respire less than the smaller size groups, but, depending on the region studied and method of estimation, the mesozooplankton have been estimated to respire up to $32 \%$ of the carbon fixed in global primary production (del Giorgio \& Duarte 2002, Hernández-León \& Ikeda 2005).

Copepods are the dominant mesozooplankton group in terms of abundance and biomass in most sea areas (reviewed by Ikeda et al. 2001), channeling energy from primary producers to the higher tropic levels, either directly (Steele 1974) or indirectly via microzooplankton (Kleppel 1993, Calbet \& Landry 2004). At temperate and higher latitudes the population dynamics of most neritic copepod species are correlated with the phytoplankton spring bloom, which typically supports high egg production and cohort development (Jónasdóttir et al. 2002, Koski 2007). As the spring bloom consists mainly of diatoms (Steele 1974), the response of copepods to these algae has received much attention. Diatoms have been reported to affect the egg production rate and hatching success, both with a positive correlation between egg production and diatom biomass (Irigoien et al. 2000a,b, Jónasdóttir et al. 2002) and with the opposite pattern due to the harmful effects of diatoms (see Ban et al. 1997, Ianora \& Miralto 2010).

Respiration of copepods and other planktonic organisms has been assessed in many studies, but the potential effects of food quality and toxicity of diatoms have not previously been considered in this context. It is well documented that copepod respiration may be influenced by the environmental temperature and body size (Ikeda et al. 2001), as well as the locomotory activity, and the specific dynamic action (SDA), which especially represents the energetic expenses of protein and lipid synthesis (Kiørboe et al. 1985, Thor 2000). Some authors suggest that respiration increases with increasing food supply (see Båmstedt \& Tande 1988, Takahashi et al. 2002), whereas others have shown no significant effects of food (Vidal 1980). For smaller size groups, previous results indicate that pelagic respiration increases following the phytoplankton spring bloom, suggesting a dependence of pelagic respiration on primary production (Caffrey et al. 1998), chlorophyll a and particulate organic carbon (Robinson et al. 2002a) and bacteria production (Jensen et al. 1990).

In the present study we measured the minimum carbon requirements (CR) through respiration measurements of the planktonic community, divided into 4 size fractions, dominated by mesozooplankton, microzooplankton, nanoplankton and bacterioplankton. The study covered different phases of the phytoplankton bloom, with different degrees of dominance by the diatom Skeletonema marinoi. One goal of the study was to give a budgetary description of the carbon transfer in the planktonic community throughout the development of the phytoplankton bloom. The other goal was to evaluate whether the succession of the blooms affected the carbon transfer of different size groups in the community. $S$. marinoi is known to produce polyunsaturated aldehydes (PUAs) mainly heptadienal, octadienal and octatrienal, which have previously been identified as the potential reasons for the detrimental effects on copepods (Ianora \& Miralto 2010 and references therein). In addition, $S$. marinoi produces a wide variety of metabolites, the production of which changes dynamically during different growth phases (Vidoudez \& Pohnert 2008, Barofsky et al. 2009). During the study period, we would thus expect changes in the respiratory $\mathrm{CR}$ of the groups in relation to the abundance of PUAproducing $S$. marinoi. Special emphasis was put on Calanus finmarchicus, a dominant copepod species in the study area, with its main egg production taking place during the phytoplankton spring bloom (Jónasdóttir et al. 2002, Koski 2007). This species was also used in a feeding experiment in order to estimate the partitioning between ingested and respired carbon, corresponding to potential growth.

\section{MATERIALS AND METHODS}

\section{Mesocosm setup}

A field-based mesocosm study was carried out at the Espegrend marine biological station, University 
of Bergen, Norway, situated in the Raunefjord $\left(60.1618^{\circ} \mathrm{N}, 5.1388^{\circ} \mathrm{E}\right)$ from 14 to 28 April 2008 (Day 0 to Day 14), with the general purpose of evaluating if and how diatoms affect the dynamics of the planktonic ecosystems. A detailed description of the mesocosm design is given in Nejstgaard et al. (2006), and a general overview of the experiment and its main results will be presented elsewhere. In short, 6 floating transparent (ca. $11 \mathrm{~m}^{3}$ volume, $2 \mathrm{~m}$ diameter, $4.5 \mathrm{~m}$ deep) polyethylene enclosures (i.e. mesocosm bags) were filled in situ with unfiltered seawater, including its content of all size fractions (from bacteria to mesozooplankton) of organisms from $4 \mathrm{~m}$ depth just outside the mesocosm and added nutrients. We also added the diatom Skeletonema marinoi, from a monoculture raised in the laboratory, to some of the bags. We used a large submersible centrifugal pump (ITT Flycht Model 3085-182), specially designed to minimize damage to organisms. The study included 3 different treatments (Mesocosms B, C and F). On Day 0, all 3 mesocosms received inorganic nutrients consisting of ca. $0.4 \mu \mathrm{mol} \mathrm{\textrm {l } ^ { - 1 }}$ phosphate and ca. $4.2 \mu_{\mathrm{mol}} \mathrm{l}^{-1}$ nitrate. Mesocosms $\mathrm{C}$ and $\mathrm{F}$ also received $3.6 \mu \mathrm{mol} \mathrm{l}^{-1}$ silicate, and Mesocosm F was inoculated with cultured $S$. marinoi to a final concentration of ca. 1000 cell $\mathrm{ml}^{-1}$. We thus expected a general increase in all phytoplankton groups in Mesocosm B, a diverse diatom bloom in Mesocosm C and S. marinoi dominance in Mesocosm F. The 3 mesocosms were sampled on 4 occasions, corresponding to pre-bloom conditions (Days 3 to 4), peak-bloom conditions (Days 6 to 7 ) and post-bloom conditions (Days 9 to 10 and 12 to 13). The different treatments and measured variables are listed in Table 1.

Hydrographical profiles and water sampling were taken daily between 07:00 and 08:30 h, and incubations for respiration measurements were usually started immediately and always within $3 \mathrm{~h}$ of sampling. Incubations were always carried out at in situ temperature, which varied between 6 and $8^{\circ} \mathrm{C}$ during the experiments. The measured variables in all mesocosms included primary production (PP), particulate organic carbon (POC) and nitrogen (PON), chlorophyll a $(\mathrm{chl} a)$, phytoplankton, protozoan and zooplankton community, chemical composition (fatty acid, sterol and PUA) and copepod physiological responses.

Environmental data are mainly presented elsewhere (Jónasdóttir et al. 2011, Vidoudez et al. 2011); thus, we only give a brief description of the methods used in the present study. PP used for scaling the planktonic carbon requirements was measured from in situ incubations outside the enclosures at 1, 3 and $5 \mathrm{~m}$ depth during $6 \mathrm{~h}$ around noon, using the ${ }^{14} \mathrm{C}$ incorporation technique (Steeman-Nielsen 1952). PP in the different enclosures was calculated as $[2 / 4.5 \times$ $(1 \mathrm{~m}+3 \mathrm{~m})+0.5 / 4.5 \times(5 \mathrm{~m})]$, where $1 \mathrm{~m}, 3 \mathrm{~m}$ and $5 \mathrm{~m}$ represent the measured $\mathrm{PP}$ at the respective depths.

As a proxy for total phytoplankton community biomass development total chl a concentrations were determined daily in the mesocosm bags by filtering duplicate water samples onto $0.2 \mathrm{~mm}$ Gelman polycarbonate filters (47 $\mathrm{mm}$ diameter). In addition, we did 1 series of single serial fractionations onto 10, 5, 1 and $0.2 \mathrm{~mm}$ Gelman polycarbonate filters $(47 \mathrm{~mm}$ diameter). We used the sum of all fractions, but the results from the individual fractions are shown in Jónasdóttir et al. (2011). The filters were extracted immediately in $90 \%$ acetone overnight at $4^{\circ} \mathrm{C}$ and then analyzed using a Turner Designs 10-AU fluorometer (Turner Designs).

Results on phytoplankton, protozoan and chemical variables were used in a principal component analysis (PCA) to examine whether there were any differences between treatments. For the analyses of the carbon requirements of the 4 size groups we used a multiple stepwise regression. Phytoplankton was counted in vivo by a Cytobuoy ${ }^{\mathrm{TM}}$ scanning flowcytometer (CytoBuoy b.v. Woerden) and by a FlowCAM II ${ }^{\mathrm{TM}}$ (Fluid Imaging Technologies), while major protozoan $>15 \mu \mathrm{m}$ were measured by the FlowCam. Further details on the methods can be found in

Table 1. Mesocosm set up showing the 3 different treatments and the day measurements for the respiratory carbon requirements of mesozooplankton, microzooplankton, nanoplankton and bacterioplankton were taken. Treatments: nitrate (N) at a concentration of $4.2 \mathrm{~m} \mathrm{\mu mol} \mathrm{l}^{-1}$, phosphate (P) at a concentration of $0.4 \mu \mathrm{mol} \mathrm{l^{-1 }}$, silicate (Si) at a concentration of $3.61 \mu \mathrm{mol} \mathrm{l}^{-1}$, Skeletonama marinoi (SKE) addition at a final concentration of $1000 \mathrm{cells} \mathrm{ml}^{-1}$

\begin{tabular}{|lccccc|}
\hline \multirow{2}{*}{ Mesocosm } & \multirow{2}{*}{ Treatment } & \multicolumn{4}{c|}{ Day of measurement } \\
\cline { 3 - 6 } & & Mesozooplankton & Microzooplankton & Nanoplankton & Bacterioplankton \\
\hline B & N + P & $3,6,9,12$ & $3,6,9,12$ & $4,7,10,13$ & $4,7,10,13$ \\
C & N + P + Si & $3,6,9,12$ & $3,6,9,12$ & $4,7,10,13$ & $4,7,10,13$ \\
F & N + P + Si + SKE & $3,6,9,12$ & $3,6,9,12$ & $4,7,10,13$ & $4,7,10,13$ \\
\hline
\end{tabular}


Jónasdóttir et al. (2011). PUA, fatty acid and sterol were analyzed as described in Vidoudez et al. (2011) and Jónasdóttir et al. (2011).

Average mesozooplankton biomass was used to calculate the mesozooplankton carbon requirement per unit of body mass carbon, as measured in our experiments, to mesozooplankton carbon requirement per liter in the mesocosm bag. At the start of the experiment, both before and after filling of the mesocosm bags, $10 \mathrm{~m}^{3}$ samples of the water used for filling the bags was filtered through $90 \mu \mathrm{m}$ plankton gauze, and the retained material was preserved in $4 \%$ buffered formaldehyde. These 3 samples were treated as replicates. At the end of the experiment, a sample of ca. $7 \mathrm{~m}^{3}$ from each mesocosm bag was collected with a submersible pump and filtered through $90 \mu \mathrm{m}$ plankton gauze, and the retained material was preserved in $4 \%$ formaldehyde.

The average mesozooplankton biomass at the start and end of the experiment was calculated as the sum of species-specific body mass, based on samples analyzed for species and stage distributions, size measurements and size/weight relationships (described in Nejstgaard et al. 2006). Since respiration incubations of the 4 groups covered a period exceeding $1 \mathrm{~d}$, we related the copepod and community response to the food variable measured over an average of $2 \mathrm{~d}$ (see 'Results').

\section{Copepod clearance and ingestion}

Copepod grazing on the phytoplankton community was estimated once, in a separate experiment on 20 April 2008 (Day 5), using ${ }^{14} \mathrm{C}$-labelled Rhodomonas baltica as a tracer. For this purpose, a $200 \mathrm{ml}$ culture of $R$. baltica was grown under constant light at ca. $8^{\circ} \mathrm{C}$ in F2 medium (Guillard \& Ryther 1962), together with $25 \mathrm{mCi}$ of sodium bicarbonate, $\mathrm{NaH}^{14} \mathrm{CO}_{3}$, for $>6 \mathrm{~d}$.

At the start of the experiment, ca. $50 \mathrm{ml}$ of the culture was diluted in $0.2 \mu \mathrm{m}$ filtered seawater (FSW), and most of the water was discarded by gently filtering through a $1 \mu \mathrm{m}$ membrane filter. This was repeated 6 times, thereby eliminating the remaining ${ }^{14} \mathrm{C}$ in the water. The algal suspension was then diluted to $50 \mathrm{ml}$ with FSW, and triplicate samples of $1 \mathrm{ml}$ were taken for cell counts and radioactivity measurements. The samples for radioactivity measurements were transferred to scintillation vials, $30 \mathrm{\mu l}$ of $3 \mathrm{M}$ hydrochloride acid $(\mathrm{HCl})$ was added, the samples were shaken for several hours to eliminate dissolved inorganic carbon, and $10 \mathrm{ml}$ of scintillation cocktail was added for scintillation counting in a
Beckman LS 6500 scintillation counter. A separate calibration curve for cell number versus radioactivity was prepared, using a range of 50 to 500000 cells, 2 replicates at each of 5 concentrations, which showed that the radioactivity (DPM, disintegrations per minute) was linearly related to cell number $\left(\mathrm{R}^{2}=\right.$ 1.00; data not shown).

Calanus finmarchicus (mainly Stage 5 copepodites) was collected from a station in the Raunefjord, ca. $1.5 \mathrm{~km}$ from the mesocosms, by gentle towing from 0 to $20 \mathrm{~m}$ depth with a $200 \mu \mathrm{m}$ plankton net, using a large, non-filtering cod-end. Copepodites were kept in FSW overnight and afterwards acclimated to the mesocosm water for at least $1 \mathrm{~d}$. Water from each mesocosm was filled up in 8 replicate incubation bottles of ca. $250 \mathrm{ml}$. Groups of 10 copepods were sorted out in small vials in FSW, and each group was added to an incubation bottle. After $30 \mathrm{~min}$ (time $=0$ ), ca. 1000 cells $\mathrm{ml}^{-1}$ (final concentration) of ${ }^{14} \mathrm{C}$-labelled Rhodomonas baltica culture was added, which always made up $<5 \%$ of the total available particulate carbon. Two subsamples for scintillation counting of the food medium were taken at the start and end of the experiment. The bottles were kept in the dark at ambient temperature, and the incubation was terminated after 20 min by emptying the bottles onto a $200 \mu \mathrm{m}$ sieve.

The copepods were rinsed stepwise in 3 rinsing baths with FSW and finally anesthetized with a solution of MS222 in a Petri dish, where their individual prosome lengths were measured using a Wild M10 dissection microscope with a measuring eyepiece. The 10 copepods were then transferred to a scintillation vial with $1 \mathrm{ml}$ toluene, dissolved overnight, and $1 \mathrm{ml} \mathrm{FSW}$ and $30 \mu \mathrm{l}$ of $3 \mathrm{M} \mathrm{HCl}$ was added.

Thereafter the samples were treated as described above. The clearance rate $\left(F, \mathrm{ml}\right.$ ind..$\left.^{-1} \mathrm{~h}^{-1}\right)$ was estimated from the equation:

$$
F=V \times \mathrm{DPM}_{\mathrm{C}} /\left(\mathrm{DPM}_{\text {mean }} \times t\right)
$$

where $V$ is the incubation volume in millilitres, $\mathrm{DPM}_{\mathrm{C}}$ is the activity per copepod in the experimental bottle, $\mathrm{DPM}_{\text {mean }}$ is the mean activity per millilitre in the food medium between the start and end of the experiment, and $t$ is the duration of the experiment in hours. The weight-specific ingestion rate $(I, \mu \mathrm{g} \mathrm{C}[\mu \mathrm{g}$ $\mathrm{C}^{-1} \mathrm{~h}^{-1}$ ) was determined by multiplying the calculated clearance rate by the average POC $\left(C_{\text {mean }}\right)$ and dividing by copepod carbon $\left(C_{\text {copepod, }} \mu \mathrm{g} C\right)$ as given from a length-weight relationship by Hygum et al. (2000):

$$
I=F \times C_{\text {mean }} / C_{\text {copepod }}
$$


The average phytoplankton carbon during incubation $\left(C_{\text {mean }}, \mu \mathrm{g} \mathrm{C} \mathrm{l}^{-1}\right)$ was calculated using the formula:

$$
C_{\text {mean }}=\mathrm{C} \times\left(\mathrm{DPM}_{\text {mean }} / \mathrm{DPM}_{\text {start }}\right)
$$

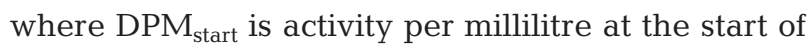
the experiment. The daily grazing rate of copepods was estimated by multiplying the hourly rate by 24 .

\section{Oxygen consumption and respiratory carbon requirement}

The respiratory $\mathrm{CR}$ of the planktonic community was estimated by using respiration measurements and conversions to $\mathrm{CR}$. For the respiration measurements we used an optode-based system with 2 plates holding 24 separate channels each (SensorDish Readers SDR2, PreSens $\mathrm{GmbH}$ ) and providing continuous readouts from each channel. This technique has proved to be advantageous compared to other conditional methods in terms of precise oxygen measurement in natural bacterial communities (Warkentin et al. 2007). Incubations were done in $5 \mathrm{ml}$ enclosed glass vials. The plates with the incubation vials were kept in a thermo-incubator with precise temperature control $\left(6\right.$ to $\left.8^{\circ} \mathrm{C}\right)$. Further details on this instrument are found in Köster et al. (2008).

We divided the plankton community into 4 size fractions, which also roughly corresponded to 4 functional groups: mesozooplankton (dominated by large calanoid copepods), size fractions $<200 \mu \mathrm{m}$ (dominated by microzooplankton), $<15 \mu \mathrm{m}$ (dominated by nanoplankton, including most of the phytoplankton), and particles passing a GF/C filter (dominated by bacterioplankton). For mesozooplankton, we used Calanus finmarchicus Stage 5 (CV) copepodites in our experiments, which were sorted out immediately after collection, transferred to 11 beakers with water from the mesocosm, and left for adaptation (see above). After adaptation, copepods were sorted into groups of 4 individuals, which were placed in $5 \mathrm{ml}$ incubation vials with newly collected mesocosm water. For the 3 other fractions of organisms, we used mesocosm water passed through a $200 \mu \mathrm{m}$, a $15 \mu \mathrm{m}$ plankton gauze and a GF/C filter, and defined microzooplankton as the fraction retained on the plankton gauze between 15 and $200 \mu \mathrm{m}$, nanoplankton as the fraction retained on the finer gauze $(<15 \mu \mathrm{m})$ and a GF/C filter, and bacterioplankton as the fraction passing through the GF/C filter. The producer defines an efficient retention as $1.2 \mu \mathrm{m}$ (see www. vgdusa.com/whatman-glass-fiber-filters.htm), which means that larger bacteria might be retained by the filter and the smallest phytoplankton might pass through.

Each experimental series consisted of 6 replicates and 2 controls, and we defined the net respiration rate as the difference between each replicate and the average of the 2 controls. The controls consisted of $0.2 \mu \mathrm{m}$ FSW from the mesocosms. The experiments were run in darkness at the ambient mesocosm temperature of 6 to $8^{\circ} \mathrm{C}$, using a thermo-incubator. Data was recorded every $5 \mathrm{~min}$ for copepods and microzooplankton and every 1 min for nanoplankton and bacterioplankton. The mesozooplankton incubations ran for $10 \mathrm{~h}$, whereas the other groups were recorded for $>20$ to $22 \mathrm{~h}$. The copepods used in the experiment were retained and preserved in $4 \%$ formaldehyde for later size measurements and body-mass estimations, in order to calculate CR per unit body carbon.

The recorded data on oxygen concentration over time in each incubation vessel were used in a linear regression analysis, where the slope of the regression line gave the actual respiration rate. The fit of the data to the regression equation was always high, indicating a rather constant respiration rate. CR was estimated from oxygen consumption, using a respiratory quotient (RQ) of 0.97 (Ikeda et al. 2000) and assimilation efficiencies (AE) of 0.75 for mesozooplankton and 0.8 for microzooplankton (see Lima et al. 2002). For nanoplankton, which was dominated by phytoplankton, no AE was used (i.e. a factor of 1). The calculations were:

$$
\mathrm{CR}=(R \times 12 / 32 \times \mathrm{RQ}) / \mathrm{AE}
$$

The CR of the 4 groups was finally compared to PP, in order to calculate how much of the produced carbon was consumed (respired) by the different groups. This gave a minimum value, since our method did not account for carbon incorporation into the body (i.e. growth).

\section{Statistical analysis}

Comparison of clearance and ingestion between mesocosms were tested using a 1-way analysis of variance (ANOVA). If the assumptions for the ANOVA were not met, we used a non-parametric Kruskal-Wallis (KW) test. A 2-way ANOVA was used to test for the differences in $\mathrm{CR}$, using day number and mesocosm (B, C, F) as factors. PCA with Varimax rotation was conducted on $\mathrm{CR}$ and the factors fatty acid, sterol, phytoplankton, protozoan, chl $a$, PP and PUA. A proxy variable, representing the group of sig- 
nificantly correlated variables on each different principle component, was tested against $\mathrm{CR}$, using multiple stepwise regression analysis. All tests were conducted with the use of the SPSS 16.0 and SigmaStat 3.5 statistical package.

\section{RESULTS}

\section{Environmental conditions}

The surface water temperature increased from ca. 6 to ca. $8^{\circ} \mathrm{C}$ from Day 1 to Day 14 . Salinity showed only small variations, ranging from 30.1 to 32.4 . The chl a concentration during the study period increased from ca. $1 \mathrm{gg} \mathrm{l}^{-1}$ in the 3 mesocosms to between 15 (Mesocosm C) and 25 (Mesocosm F) $\mu \mathrm{g} \mathrm{l}^{-1}$ at the peak of the bloom on Days 7 and 8 (Fig. 1). Thereafter, the concentration showed a pronounced decrease in Mesocosm F to about $1 \mu \mathrm{g} \mathrm{l}^{-1}$, whereas chl a remained relatively high in Mesocosms B and $\mathrm{C}$, although with a decrease during the last day. The average $\mathrm{PP}$, as an average for the $4.5 \mathrm{~m}$ water column and for the whole period, was 22 (Mesocosm B) 27 (Mesocosm C) and 20 (Mesocosm F) $\mathrm{\mu g} \mathrm{Cl}^{-1} \mathrm{~h}^{-1}$, with a total range in single days from 2 to $45 \mu \mathrm{g} \mathrm{Cl}^{-1} \mathrm{~h}^{-1}$.

Phytoplankton, represented by Skeletonema marinoi, Phaeocystis pouchetii and coccolithophores, varied in distribution between the 3 mesocosms. Phaeocystis sp. was the dominating species in Mesocosm B, and S. marinoi dominated in Mesocosm F, whereas, in Mesocosm C, all phytoplankton were equally abundant. Furthermore, the protozoan com-

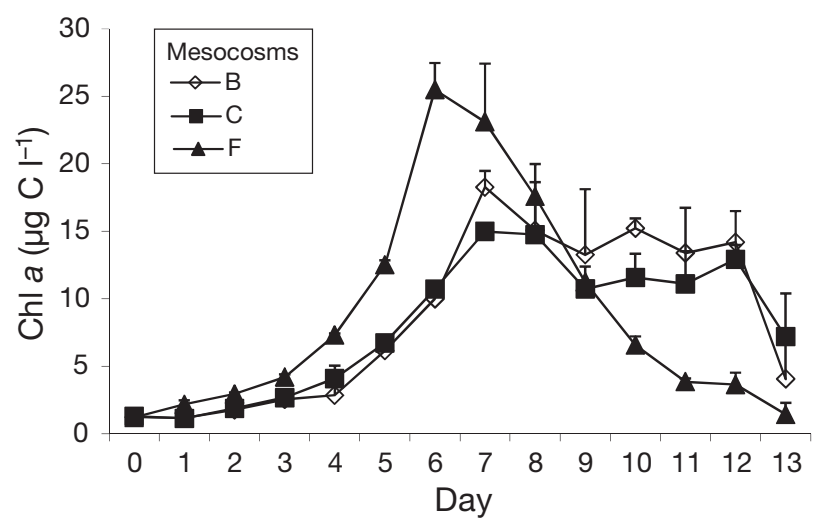

Fig. 1. Development of total chlorophyll a concentration $\left(\mu \mathrm{g}^{-1}\right.$ collected with GF/C filters and polycarbonate membrane filters) in Mesocosms B (nitrogen + phosphorus added), C (nitrogen + phosphorus + silicate added) and $\mathrm{F}$ (nitrogen + phosphorus + silicate +1000 Skeletonema marinoi cell $\mathrm{ml}^{-1}$ added) munity was dominated by ciliates and heterotrophic dinoflagellates, mainly Gyrodinium spirale, Protoperidinium bipes and Gyrodinium dominans. More details on dynamic differences are described in Jónasdóttir et al. (2011).

Average mesozooplankton biomass was very similar in all studied mesocosms, with the highest biomass in Mesocosm C and the lowest in Mesocosm F (Table 2). The calanoid copepods Acartia longiremis, Calanus finmarchicus and Temora longicornis were dominant, contributing ca. $90 \%$ of the total zooplankton biomass in all 3 mesocosms. Other taxa such as meroplankton larvae and appendicularians contributed only a small fraction of the total mesozooplankton. Further details on species composition will be discussed elsewhere (J. C. Nejstgaard et al. unpubl. data).

\section{Chemical composition}

PUA was dominated by heptadienal, octadienal and decadienal components, with the concentration reflecting the development of Skeletonema marinoi (M. Koski et al. in press). The fatty acids, dominated by 18:3 (n-6), 22:6 and 20:5, followed the same pattern as the PUA concentration but remained relatively high after the peak of the phytoplankton blooms. The main particulate sterols were cholesterol, brassicasterol and sitosterol, and these increased over time in Mesocosms B and C, but decreased in Mesocosm $F$ after the peak of the bloom. More details on PUA, fatty acid and sterol dynamics and concentrations in the mesocosms are described elsewhere (Jónasdóttir et al. 2011, Vidoudez et al. 2011).

\section{Environmental differences between mesocosms}

PCA of the 13 variables in the food environment of the 3 mesocosms defined 3 major components that together contributed $81 \%$ of the total variance between the 3 food environments (Table 3). The first component was composed of 22:6(n-3) fatty acid, PUFA, total fatty acid, protozoans (comprised of the ciliates, the heterotrophic dinoflagellates, Gyrodinium spirale, Protoperidinium bipes and Gyrodinium dominans) and 18:3(n-6) fatty acid. The second component was composed of Phaeocystis sp., coccolithophores, sterol and PP. The third component was formed by Skeletonema marinoi, PUA, total chl a and 20:5(n-3) fatty acid. It thus appeared that most 
Table 2. Skeletonema marinoi concentration (cells $\mathrm{ml}^{-1}$ ), mesozooplankton biomass (average between day start and end; $\mu \mathrm{g} \mathrm{C}$ $\mathrm{l}^{-1}$ ), weight-specific ingestion (WSI) and respiratory carbon requirement (WSCR; $\mu \mathrm{g} \mathrm{C}[\mu \mathrm{g} \mathrm{C}]^{-1} \mathrm{~d}^{-1}$, means $\pm \mathrm{SD}$ ), mesozoo-

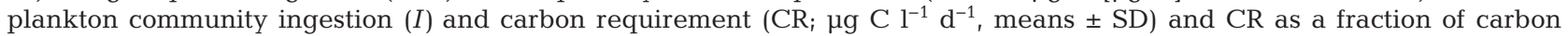
ingestion $(\mathrm{CR} / \mathrm{I})$ in Mesocosms B, C and F using Calanus finmarchicus. All data were measured on Day 5

\begin{tabular}{|c|c|c|c|c|c|c|c|}
\hline Mesocosm & S. marinoi & $\begin{array}{c}\text { Mesozooplankton } \\
\text { biomass }\end{array}$ & WSI & WSCR & Community $(I)$ & Community (CR) & $\mathrm{CR} / I$ \\
\hline B & 63 & 43 & $0.39 \pm 0.12$ & $0.09 \pm 0.02$ & $17.04 \pm 5.40$ & $3.89 \pm 0.70$ & $0.23 \pm 0.04$ \\
\hline $\mathrm{C}$ & 173 & 45 & $0.36 \pm 0.04$ & $0.11 \pm 0.01$ & $16.41 \pm 1.90$ & $5.12 \pm 0.53$ & $0.31 \pm 0.04$ \\
\hline F & 5567 & 39 & $0.29 \pm 0.03$ & $0.12 \pm 0.03$ & $11.48 \pm 1.42$ & $4.67 \pm 0.89$ & $0.41 \pm 0.09$ \\
\hline
\end{tabular}

Table 3. Principal component analysis, using a Varimax rotation with Kaiser normalization in 5 iterations. Percentage indicates the contribution of each principal component $(\mathrm{PC})$ to the total variance (combined $=81 \%$ ). Highly significant correlations $(>0.7)$ for each component are printed in bold. The variables which were chosen for the stepwise multiple regression analysis are underlined. PUFA: polyunsaturated fatty acids; FA: fatty acids; PUA: polyunsaturated aldehydes

\begin{tabular}{|lccc|}
\hline & PC1 & PC2 & PC3 \\
& $47 \%$ & $22 \%$ & $12 \%$ \\
\hline Docosahexaenoic acid; 22:6(n-3) & $\underline{\mathbf{0 . 9 7 4}}$ & & \\
PUFA & $\mathbf{0 . 9 2 9}$ & 0.194 & 0.269 \\
Total FA & $\mathbf{0 . 9 0 9}$ & 0.125 & 0.391 \\
Protozoan & $\mathbf{0 . 8 5 6}$ & & -0.125 \\
Linoleic acid; 18:3(n-3) & $\mathbf{0 . 8 1 1}$ & 0.393 & 0.179 \\
Phaeocystis sp. & & $\underline{\mathbf{0 . 9 4 4}}$ & -0.131 \\
Coccolithophores & -0.102 & $\mathbf{0 . 8 1 5}$ & 0.283 \\
Sterol & 0.444 & $\mathbf{0 . 8 1 0}$ & \\
Primary production & 0.206 & $\mathbf{0 . 7 9 8}$ & 0.133 \\
Skeletonema marinoi & 0.120 & & $\mathbf{0 . 9 6 4}$ \\
PUA & 0.174 & & $\mathbf{0 . 9 3 5}$ \\
Chlorophyll a & & 0.555 & $\mathbf{0 . 7 6 9}$ \\
Eicosapentaenoic acid; $20: 5(\mathrm{n}-3)$ & 0.666 & & $\mathbf{0 . 7 0 2}$ \\
\hline
\end{tabular}

fatty acids and the protozoan community showed a similar succession throughout the experiment, but had different dynamics than the phytoplankton species S. marinoi and Phaeocystis sp. which, in turn, developed differently from each other. Based on the PCA, we chose 22:6(n-3) fatty acid as the representative of PC1, Phaeocystis sp. as the representative of PC2 and S. marinoi as the representative of PC3 for a multiple stepwise regression analysis of how CR was related to the food environment (see the following subsection).

\section{Copepod grazing and carbon requirements}

The average clearance rate of Calanus finmarchicus measured on Day 5, during late pre-bloom condi- tions, was 46, 39, and $22 \mathrm{ml}$ ind..$^{-1} \mathrm{~d}^{-1}$ in Mesocosms $B, C$ and $F$, respectively. The ingestion rate varied less and was 19 to $26 \mu \mathrm{g} \mathrm{C}$ ind. ${ }^{-1} \mathrm{~d}^{-1}$ in all mesocosms, corresponding to a daily ration of 39,36 and $29 \%$ body carbon $\mathrm{d}^{-1}$ in Mesocosms B, C and F, respectively. No significant differences between the mesocosms were observed for the ingestion rate, but the clearance rate was significantly lower in Mesocosm F than in the other 2 mesocosms (KW: $H=12$, p $<0.01$; Fig. 2).

To estimate mesozooplankton community ingestion, we multiplied the biomass and specific ingestion (Table 2). The resulting mesozooplankton community ingestion rate was high in Mesocosms $\mathrm{B}$ and $\mathrm{C}$, but lower in Mesocosm $\mathrm{F}$, corresponding to $5 \%$ of $\mathrm{PP}$ in $\mathrm{B}, 4 \%$ in $\mathrm{C}$ and $2 \%$ in $\mathrm{F}$.

Mesozooplankton community CR showed a similar trend over time for the 3 mesocosms, with an increase from pre-bloom (Day 3) to peak-bloom (Day 6), and a decrease during the post-bloom period (Day 9), with no significant differences between mesocosms (2-way ANOVA: p > 0.05; Fig. 3). Mean CR values in

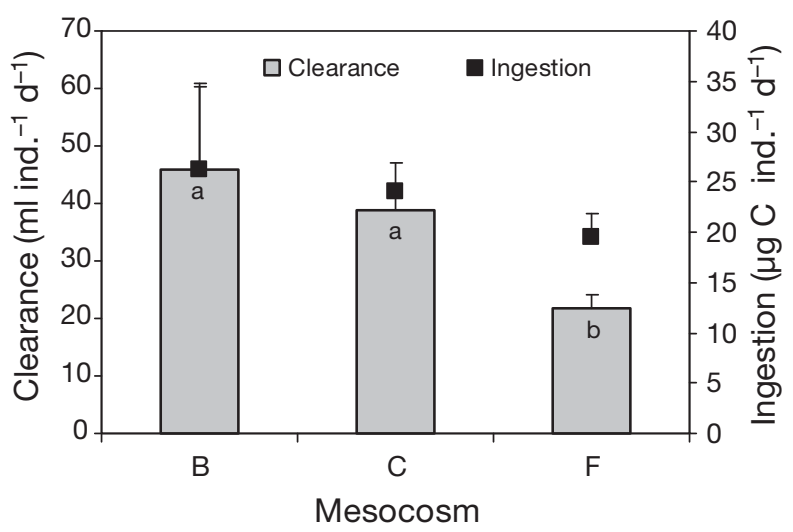

Fig. 2. Calanus finmarchicus. Clearance (ml ind. ${ }^{-1} \mathrm{~d}^{-1}$; columns) and ingestion ( $\mu \mathrm{g} \mathrm{C}$ ind. ${ }^{-1} \mathrm{~d}^{-1}$; symbols) rates in 3 different mesocosms (means $\pm \mathrm{SD}$ ). For clearance rates, different letters denote treatments that are significantly different from each other 

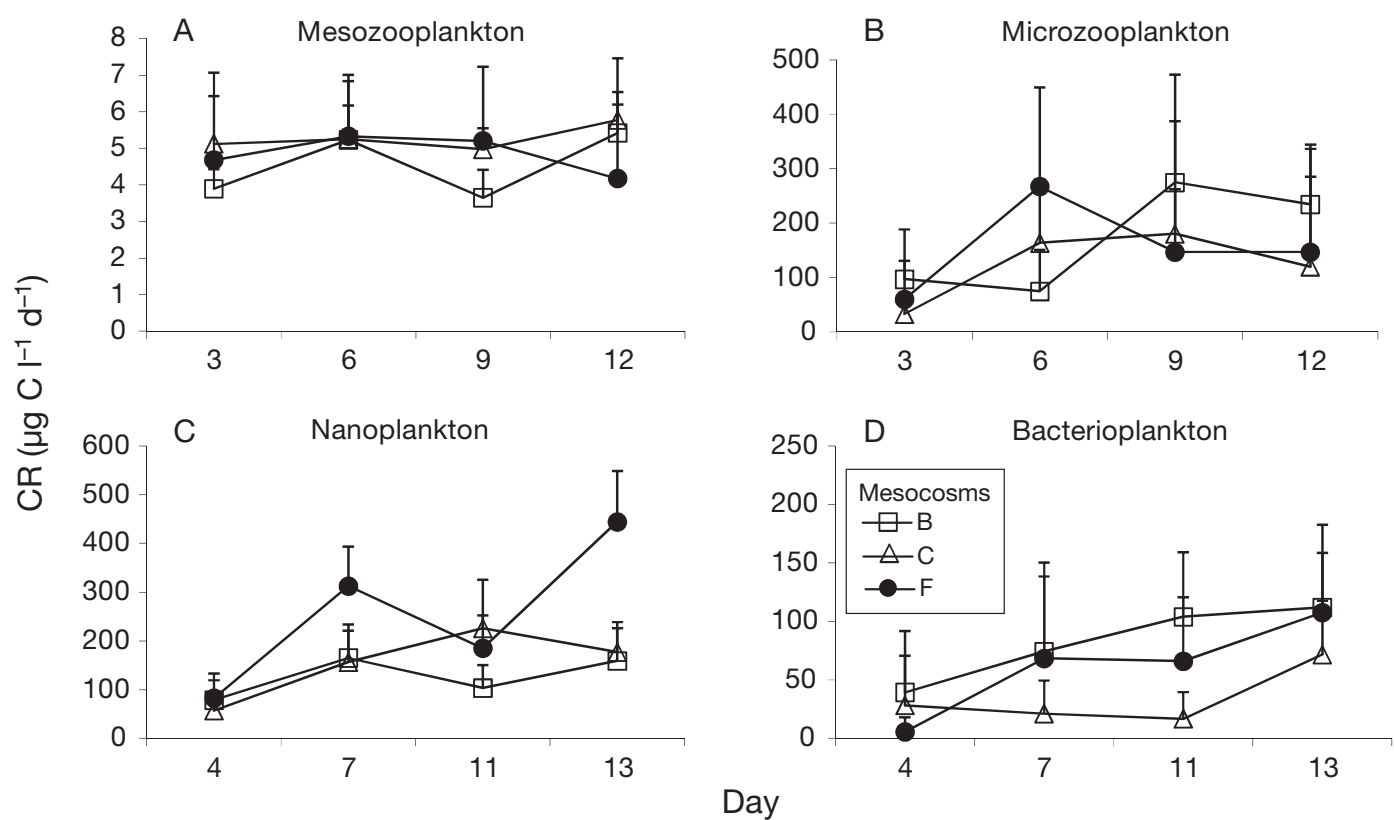

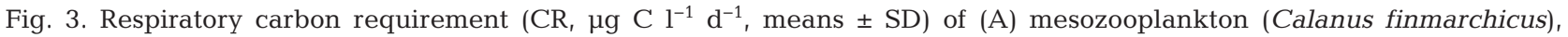
(B) microzooplankton $(15<\chi<200 \mu \mathrm{m})$, (C) nanoplankton (GF/C $<\chi<15 \mu \mathrm{m}$ ) and (D) bacterioplankton (GF/C filter) in Mesocosms B, C and F during different time course experiments



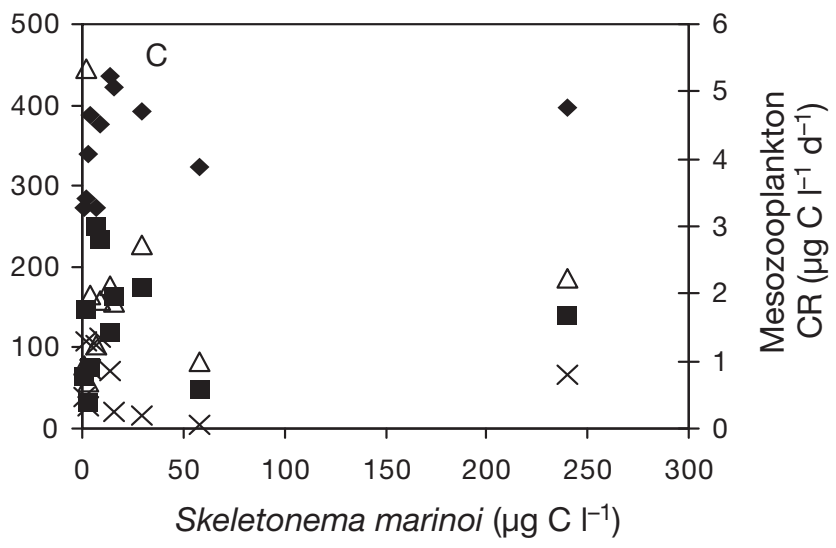

Fig. 4. Respiratory carbon requirements of different planktonic groups: mesozooplankton $(\diamond)$, microzooplankton (घ), nanoplankton $(\Delta)$ and bacterioplankton $(\times)$ as a function of (A) 22:6(n-3) fatty acid, (B) Phaeocystis sp. $\left(\mathrm{ml}^{-1}\right)$ and (C) Skeletonema marinoi $\left(\mu \mathrm{g} \mathrm{Cl}^{-1}\right.$ ). The figure shows individual relationships with highly correlated variables on each principle component (see Table 3) 
Mesocosms B, C and F were 4.5, 5.3 and 4.8 $\mu \mathrm{g} \mathrm{C} \mathrm{l}^{-1}$ $\mathrm{d}^{-1}$, respectively. The individual daily specific $\mathrm{CR}$ varied only a little, with an average of $11 \%$ in Mesocosm B and $12 \%$ of body carbon in Mesocosms C and F. For the daily respiratory carbon loss at Day 5, it was lower than the daily ingestion of carbon derived from the feeding experiments $(23,31$ and $41 \%$, respectively; Table 2).

\section{Microbial carbon requirements}

The CR of microzooplankton in the mesocosms showed no significant trend over time or any differences between the mesocosms (2-way ANOVA: p > 0.05), with a total range from 31 (Day 3, Mesocosm C)

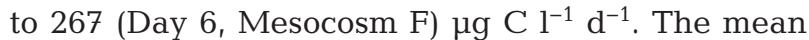
values for Mesocosms B, C and F were, respectively, 156, 122 and $150 \mu \mathrm{g} \mathrm{C}^{-1} \mathrm{~d}^{-1}$ (Fig. 3).

For nanoplankton, the $\mathrm{CR}$ was generally variable, ranging from 55 to $444 \mu \mathrm{g} \mathrm{C}^{-1} \mathrm{~d}^{-1}$, with a significant difference between day (2-way ANOVA: $F_{3}=19$, p < $0.001)$ and the 3 mesocosms $\left(F_{2}=23, \mathrm{p}<0.001\right)$. Furthermore, the mesocosm $\times$ day interaction was also significant $\left(F_{6}=8, \mathrm{p}<0.001\right)$. In contrast, the CR of bacterioplankton showed significant differences between Mesocosms B and C (2-way ANOVA: $F_{2}=6$, $\mathrm{p}<0.05$; Tukey's test: $\mathrm{p}<0.05$ ), but without any clear trend over time. The rate ranged between 39 and $112 \mu \mathrm{g} \mathrm{C}^{-1} \mathrm{~d}^{-1}$ in Mesocosm B and from 21 to $71 \mu \mathrm{g}$ $\mathrm{C}^{-1} \mathrm{~d}^{-1}$ in Mesocosm C. In Mesocosm $\mathrm{F}$, the CR of bacterioplankton showed a strong trend over time, with starting levels

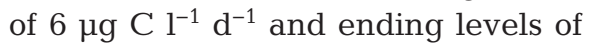
$107 \mu \mathrm{C} \mathrm{C}^{-1} \mathrm{~d}^{-1}$, corresponding to an 18-fold increase (Fig. 3).

Since meso- and microzooplankton on the one hand and nano- and bacterioplankton on the other hand were incubated on different days (see Table 1), we used the average food level of the $2 \mathrm{~d}$ when evaluating relationships using multiple stepwise regression analysis. The relationship between $\mathrm{CR}$ for the 4 groups and 22:6(n-3) fatty acid, Phaeocystis sp. and Skeletonema marinoi are shown in Fig. 4. No significant relationship was observed for the CR of mesozooplankton, but microzooplankton CR was best explained by a combination of all 3 variables $(79 \%$ of the variation). The CR of nanoplankton was best explained by its relationship with 22:6(n-3) fatty acid, and that of bacterioplankton by the combination with 22:6(n-3) fatty acid and Phaeocystis sp. The model explained 66 and $74 \%$ of the total variation for the 2 groups, respectively (Table 4, Fig. 3).

\section{Partitioning of respiratory carbon requirements and relation to primary production}

The CR of mesozooplankton was $<2 \%$ of total plankton CR in all mesocosms (Fig. 5). Nanoplankton generally contributed $50 \%$ in Mesocosms C and F, while microzooplankton was higher in Mesocosms B and $\mathrm{C}$ during the post-bloom period. Bacterioplankton appeared to be intermediate in respiratory $\mathrm{CR}$, usually below or close to $20 \%$ in all mesocoms.

In terms of the cycling of carbon, mesozooplankton was the least important component, with $<6 \%$ of the PP being respired. Microzooplankton and nanoplankton contributed more, with a range of 15 to $205 \%$ and 7 to $612 \%$ of PP, respectively. The contribution of bacterioplankton was intermediate, ranging from 1 to $50 \%$ of PP in all mesocosms (Fig. 6).

\section{DISCUSSION}

Our results strengthen the general observation that the dynamics in the phytoplankton spring bloom in northern coastal environments is only marginally

Table 4. Results of multiple stepwise regressions and their significance for the models on the respiratory carbon requirement $\left(\mathrm{CR}_{i} \mu \mathrm{g} \mathrm{C} \mathrm{l}^{-1} \mathrm{~d}^{-1}\right)$ and Skeletonema marinoi ( $\mu \mathrm{g} \mathrm{Cl}^{-1}$ ), Phaeocystis sp. (colonies $\mathrm{ml}^{-1}$ ) and the 22:6(n-3) fatty acid. The values are best fits of forward stepwise regressions. Model statistics show the number of observations (N) in the regression, and the coefficient of determination of the multiple regression $\left(R^{2}\right)$ and the significance ( $p$-value) of the multiple regression. Significance of the variable within the regression is given where ${ }^{*} p<0.05,{ }^{* *} p<0.01$

\begin{tabular}{|c|c|c|c|c|}
\hline Respiratory CR & Variable & $F$-to-remove & F-to-enter & $\mathrm{p}$ \\
\hline \multicolumn{5}{|c|}{ Microzooplankton } \\
\hline $\mathrm{N}=12$ & S. marinoi & 9.169 & & $0.046^{*}$ \\
\hline $\mathrm{R}^{2}=0.79$ & Phaeocystis sp. & 13.67 & & $0.006^{* *}$ \\
\hline$p=0.005$ & 22:6(n-3) fatty acid & 6.491 & & $0.034^{*}$ \\
\hline \multicolumn{5}{|l|}{ Nanoplankton } \\
\hline $\mathrm{N}=12$ & 22:6(n-3) fatty acid & 19.408 & & $0.001^{* *}$ \\
\hline $\mathrm{R}^{2}=0.66$ & S. marinoi & & 2.276 & 0.162 \\
\hline$p=0.001$ & Phaeocystis sp. & & 0.589 & 0.461 \\
\hline \multicolumn{5}{|c|}{ Bacterioplankton } \\
\hline $\mathrm{N}=12$ & Phaeocystis sp. & 5.95 & & $0.037^{*}$ \\
\hline $\mathrm{R}^{2}=0.744$ & 22:6(n-3) fatty acid & 20.241 & & $0.001^{* *}$ \\
\hline$p=0.002$ & S. marinoi & & 0.0002 & 0.965 \\
\hline
\end{tabular}



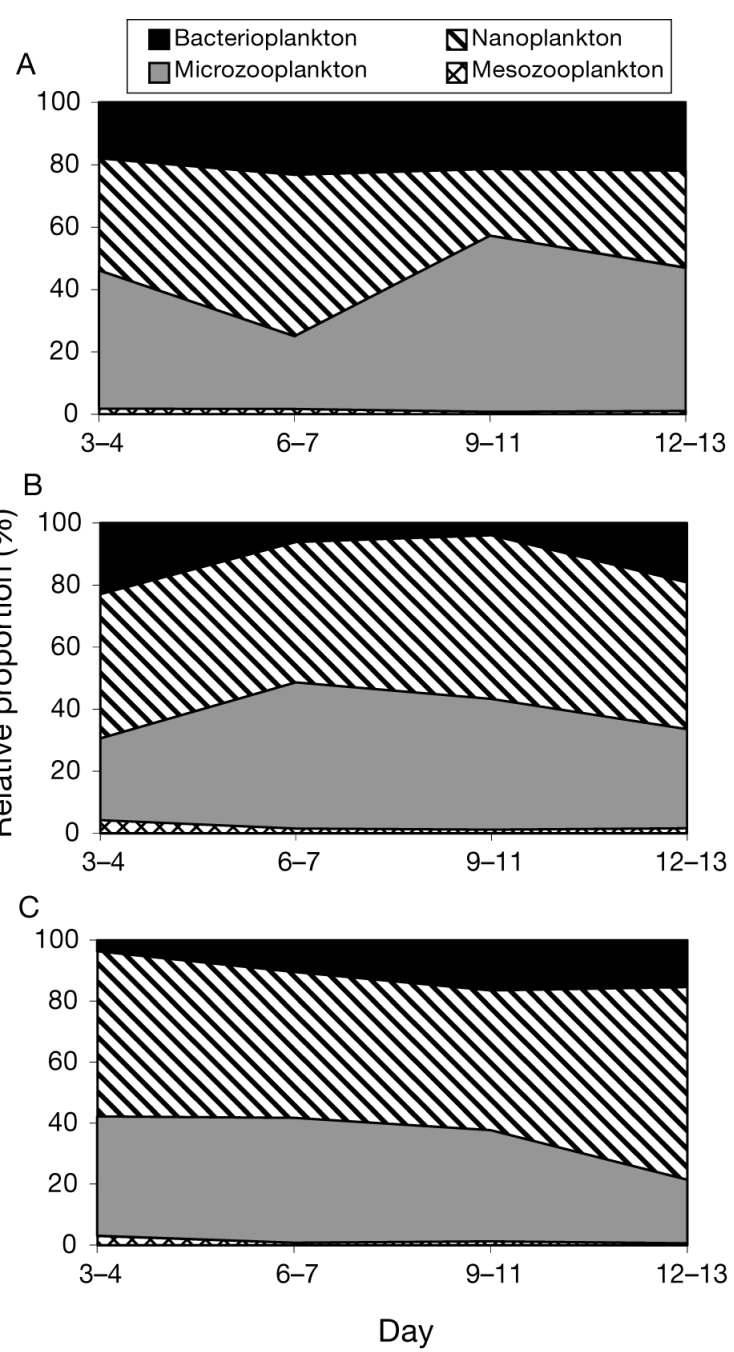

Fig. 5. Relative proportions (\%) of the respiratory carbon requirement of different size fractions in (A) Mesocosm B; (B) Mesocosm Ci (C) Mesocosm F, observed on 2 different days (see Table 1)

governed by mesozooplankton. In our study, microzooplankton and nanoplankton carbon requirements dominated community carbon requirements and consumed a substantial portion of the PP, whereas bacterioplankton showed a more variable contribution. The main reason for the low impact of mesozooplankton was the low biomass, which ranged from 39 to $45 \mathrm{\mu g} \mathrm{l}^{-1}$ as an average for the experimental period, corresponding to 2.8 to $3.3 \%$ of daily turnover of the POC standing stock in the 3 mesocosms (data not shown). However, the mesocosm zooplankton biomasses observed in the present study were within the range recorded by previous mesocosm studies and did not diverge significantly from biomasses recorded in natural water from this site (e.g. Wiborg 1954, Nejstgaard et al. 1997, 2001a,
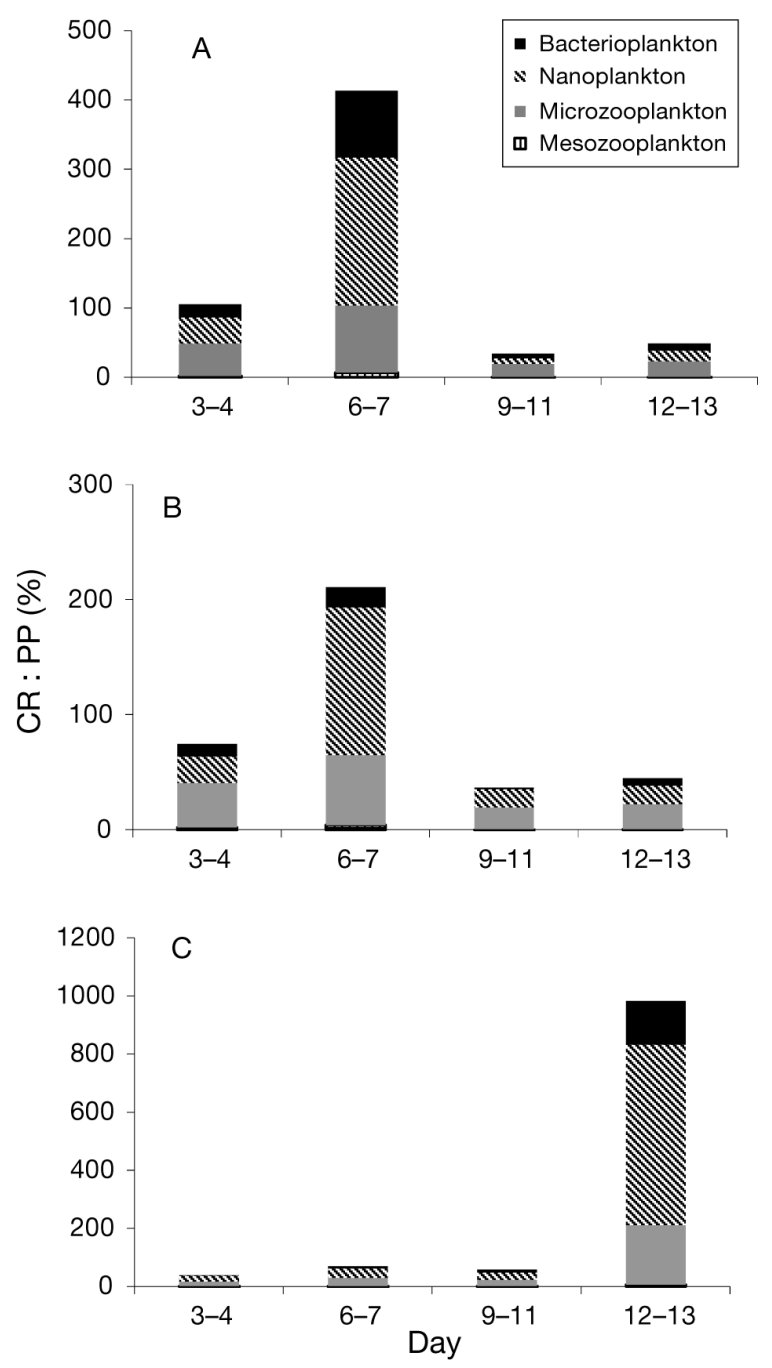

Fig. 6. Planktonic respiratory carbon requirements account for produced primary production (CR:PP, \%) in (A) Mesocosm B $;$ (B) Mesocosm Ci (C) Mesocosm F. Since there were differences in days in 4 different fractions, the PP was calculated from the average of $2 \mathrm{~d}$ (see 'Materials and methods')

2006) or other coastal sea areas (e.g Painting et al. 1993, Keister et al. 2009). Thus, with the range of mesozooplankton commonly occurring during phytoplankton blooms we should not expect a large grazing impact. These findings are discussed in detail in 'Materials and methods'.

\section{Copepod feeding and carbon requirements}

The radioactive labeling of food with the ${ }^{14} \mathrm{C}$ method is one approach to measuring ingestion, although it is not free from methodological problems. With proper labeling techniques and controls to account for all of the isotope 'pools', labeling experi- 
ments can provide accurate, quantitative feeding data, which, because of the sensitivity of the method, are particularly useful for studying zooplankton feeding behavior (Båmstedt et al. 2000). The isotope technique assumes that there is no discrimination between the natural assemblage of food particles and the added, isotopically labeled ones (Båmstedt et al. 2000). Calanus sp. is mainly a size-selective grazer, preferring larger cells such as diatoms or microzooplankton (see Hansen et al. 1994, Nejstgaard et al. 2001b, Calbet \& Saiz 2005). Using the quantitative PCR method, Barofsky et al. (2010) reported that $C$. finmarchicus showed feeding levels at least as high on the diatom Skeletonema marinoi as on the smaller cryptophyte Rhodomonas marina. As we used labeled Rhodomonas sp., the total ingestion rates presented here should be taken as a conservative estimate.

However, the estimated daily clearance and ingestion rates of Calanus finmarchicus were typically high (Fig. 2). Compared to previous studies, our results were higher than the ingestion rates measured by both gut fluorescence (Båmstedt et al. 1991, Irigoien et al. 1998) and chl a clearance (Nejstgaard et al. 1997, Hansen et al. 2000). In contrast, the rates are similar to spring bloom ingestion measured based on cell counts (Nejstgaard et al. 1997, Hansen et al. 2000, Koski 2007).

Nevertheless, the estimated respiratory $\mathrm{CR}$ of mesozooplankton was still low and showed no obvious patterns of differences over time or between mesocosms. The respiratory CR fell within the range of previous measurements in the Norwegian Sea (Thor 2000, 2002) and elsewhere (Marshall \& Orr 1958, Båmstedt \& Tande 1988). Typically, respiration is lower in food-limited copepods than in areas with high food availability (Marshall 1973). Respiration of Calanus hyperboreus has been observed to increase with increasing chl a concentration, which indicates an effect of feeding (Takahashi et al. 2002). We observed no apparent relationship between the CR and chl a concentration, Skeletonema marinoi, or other food parameters. During this experiment with spring bloom concentrations of algae, our results indicated that $C$. finmarchicus could meet their CR on a herbivorous diet alone. This result differs from the findings of many previous studies showing respiration rates exceeding phytoplankton ingestion, suggesting an importance of microzoplankton in the copepod diet (Dagg et al. 1980, Dam \& Peterson 1993, $\mathrm{Li}$ et al. 2004). The feeding preference of $C$. finmarchicus for larger microzooplankton is likely to be more pronounced during the post-bloom period or when phytoplankton concentration is low and the dominant species are small (Koski \& Wexels-Riser 2006), and when microzooplankton concentrations are relatively high.

\section{Partitioning of carbon requirements in relation to primary production}

In Norwegian coastal waters, the phytoplankton spring bloom is a period of enhanced bacterial production, as well as microzooplankton abundance (Heimdal 1974, Erga \& Heimdal 1984) and copepod recruitment (Jónasdóttir et al. 2005, Koski 2007). These heterotrophs all contribute to the consumption of organic matter. Most studies suggest that bacterioplankton (Blight et al. 1995, Robinson et al. 2002a) and microzooplankton (Calbet \& Landry 2004) are responsible for most of the pelagic respiration.

Our study showed that microzooplankton and nanoplankton contributed most, with almost half of the total CR within the plankton community, whereas bacterioplankton dominated on only one occasion. Due to the effective pore size (see above) of the GF/C filter, there might be a certain loss of bacteria through retention in the filter. Lee et al. (1995) found that $51 \%$ of natural bacterial cells were retained by a $\mathrm{GF} / \mathrm{F}$ filter. Our use of GF/C filters with a $1.2 \mu \mathrm{m}$ pore size compared to the $0.7 \mu \mathrm{m}$ pore size of GF/F filters would reduce the retention considerably, although we have no data support this assumption. Thus, a substantially lower retention of $51 \%$ would only marginally affect our results.

The average respiratory $\mathrm{CR}$ of microzooplankton and nanoplankton in Mesocosms B and C exceeded $50 \%$ of PP, while bacterioplankton consumed less, with the highest overall consumption of $50 \%$ mainly occurring in Mesocosm F. This is similar to the open Skagerrak (North Sea), where bacteria and flagellates made up $>50 \%$ of total pelagic respiration and consumed slightly more than the net PP (Rosenberg et al. 1990). Similarly, microzooplankton were estimated to consume 33 to $43 \%$ of the daily PP, in environments varying from estuarine to oceanic and from tropical to polar (Calbet \& Landry 2004).

The variation in the CR of the microbial community over time and between mesocosms was most closely related to food quality, mainly lipid composition. However, for microzooplankton, this correlation is best explained by a combination of different food types including Phaeocystis sp. and Skeletonema marinoi (Table 4). Previous studies have demonstrated a significant relationship between $\mathrm{PP}, \mathrm{chl}$ a 
and pelagic respiration (e.g Jensen et al. 1990, Rudek \& Cloern 1996, Robinson et al. 2002a), indicating the importance of phytoplankton as a factor responsible for the pelagic respiration. In our study, PP (with Phaeocystis sp. as a representative, see Table 3) correlated significantly with microzooplankton and bacterioplankton, whereas chl a (with $S$. marinoi as a representative, see Table 3) only correlated significantly with microzooplankton carbon requirements, indicating that the microzooplankton may be responsible for a significant fraction of phytoplankton loss. It has been suggested that diatoms generally can escape microzooplankton grazing due to large cell sizes and chain formation (e.g. Burkill et al. 1987). However, the cell size of Skeletonema sp. used to inoculate the mesocosms was relatively small (ca. 4 to $5 \mu \mathrm{m}$ wide $\times 10$ to $15 \mu \mathrm{m}$ long), and larger microzooplankton, such as ciliates, were abundant. These ciliates may crop single diatom cells from the end of the chains, and may also efficiently consume larger diatoms (reviewed by Nejstgaard et al. 1997).

The role of mesozooplankton in the average respiratory $\mathrm{CR}$ of the plankton community was minor $(<6 \%$ of $\mathrm{PP})$ in our study during the time of investigation. This agrees with results by Hernández-León et al. (1999) who observed that the respiration loss of mesozooplankton on the Antarctic peninsula during austral spring $\left(1\right.$ to $2.5^{\circ} \mathrm{C}$ ) is low $(<8 \%$ of $\mathrm{PP})$ due to the low mesozooplankton biomass. However, our measurements did not consider the impact of small calanoid copepods during the study period. Small calanoid copepods like Acartia clausi and A. tonsa are characterized by higher metabolic activities and biomass turnover rates compared to larger copepods (e.g. Mayzaud et al. 1992), with ca. 2-fold higher oxygen consumption per unit biomass in Acartia sp. than in Calanus finmarchicus (Thor 2000). Similar rates of oxygen consumption were also observed in Acartia sp. and Temora longicornis measured at ca. $10^{\circ} \mathrm{C}$ (Gauld \& Raymon 1953). Our calculations for mesozooplankton carbon requirements are based on $C$. finmarchicus, although both Acartia spp. (between 48 and $78 \%$ of the total mesozooplankton biomass) and Temora longicornis (3 to $11 \%$ ) were present in the mesocosms. If we assume specific CR rates twice as high for smaller copepods and take into account the biomass proportions of the 3 species, we end up with an average CR of ca. $8 \mu \mathrm{g} \mathrm{C}^{-1} \mathrm{~d}^{-1}(<10 \%$ of PP), which is not substantially higher than our original estimate. We thus conclude that, even if we assume higher metabolic activity in copepods in the mesocosms, the CR of mesozooplankton was not a dominant factor for the spring bloom succession.

\section{Carbon balance}

Integrating the production and respiration values over the entire water column allows the trophic status of the system to be evaluated (Witek et al. 2001). A switch between autotrophy and heterotrophy has been observed during the spring bloom (Lancelot \& Billen 1984, Jensen et al. 1990), suggesting that highest respiration values are likely to be associated with the development and collapse of the spring bloom. We noticed a tendency toward heterotrophy during the early bloom in Mesocosms B and C as a result of a higher CR of microzooplankton and nanoplankton, and the same tendency during post-bloom in Mesocosm F, as a consequence of decreased PP.

However, bias in the size-fractionated microbial respiratory $\mathrm{CR}$ could be caused by an increase of fast-growing organisms as a result of the removal of predators, as well as mortality of organisms during handling (see Robinson et al. 2002b). Such effects have been documented previously (Pomeroy et al. 1995). As major sources of errors, Sherr et al. (1999) attributed the enhanced growth of microzooplankton to the removal of grazers and the enhanced growth of bacterioplankton to the release of organic substrate during manipulation of samples. On the other hand, several other studies of plankton respiration in polar, tropical and temperate environments found no evidence for enhanced respiration during $24 \mathrm{~h}$ dark incubations (Blight et al. 1995, Robinson 2000, Robinson et al. 2002b).

In conclusion, our results show that mesozooplankton contributes only a small fraction of the respiratory carbon requirement to the community during a phytoplankton bloom event, and that this is independent of the dominant phytoplankton type or the total food quantity during the phytoplankton bloom. The present study also supports the traditional view of microzooplankton, nanoplankton and bacterioplankton as the major contributors of biological carbon transfer in pelagic systems. It further demonstrates that lipid composition might be a significant factor in governing the carbon requirements of the plankton community, whereas the potential toxicity of the PUA associated with Skeletonema marinoi blooms might have been insignificant during the study period.

Acknowledgements. We thank the Nordic Marine Academy, the Ministry of Higher Education, Malaysia, and the University Malaysia Terengganu for funding. We gratefully acknowledge the European FP6 Project 'EUR-OCEANS' for funding the project 'Research integration by sharing facilities and cooperative development of new approaches' led by J. C. Nejstgaard, and all our colleagues C. Augustin, A. 
Barofsky, J. Bergkvist, A. Calbet, Y. Carotenuto, B. Diekmann, J. Dutz, A. Gerecht, A. Ianora, H. H. Jakobsen, S. Jónasdóttir, M. Koski, I. Pesmatzoglou, G. Pohnert, P. Simonelli, A. Spielmeyer, C. Stangenberg, C. Troedsson, C. Vidoudez, S.-A. Wangberg and L. Yebra. Also warmest thanks to Marja Koski for extensive comments on an earlier version of this paper.

\section{LITERATURE CITED}

Alcaraz M, Packard TT (1989) Zooplankton ETS activity and respiration in the Catalan Sea (western Mediterranean). Sci Mar 53:247-251

Båmstedt U, Tande K (1988) Physiological response of Calanus finmarchicus and Metridia longa (Copepoda, Calanoida) during the winter-spring transition. Mar Biol 99:31-38

Båmstedt U, Eilertsen HC, Tande K, Slagstad D, Skjoldal HR (1991) Copepod grazing potential and its potential impact on the phytoplankton development in the Barents Sea. Polar Res 10:339-353

Båmstedt U, Gifford DJ, Irigoien X, Atkinson A, Roman M (2000) Feeding. In: Harris RP, Wiebe PH, Lenz J, Skjoldaland HR, Huntley M (eds) ICES zooplankton methodology manual. Academic Press, London, p 83-192

Ban S, Burns C, Castel C, Christou E and others (1997) The paradox of diatom-copepod interactions. Mar Ecol Prog Ser 157:287-293

Barofsky A, Vidoudez C, Pohnert G (2009) Metabolic profiling reveals growth stage variability in diatom exudates. Limnol Oceanogr Methods 7:382-390

> Barofsky A, Simonelli P, Vidoudez C, Troedsson C, Nejstgaard JC, Jacobsen HH, Pohnert G (2010) Growth phase of the diatom Skeletonema costatum influences the metabolic profile of the cells and the selective feeding of the copepod Calanus spp. J Plankton Res 32:263-272

> Blight SP, Bentley TL, Lefevre D, Robinson C, Rodrigues R, Rowlands J, Williams PJleB (1995) Phasing of autotrophic and heterotrophic plankton metabolism in a temperate coastal ecosystem. Mar Ecol Prog Ser 128:61-75

Burkill PH, Mantoura RFC, Llewellyn CA, Owens NJP (1987) Microzooplankton grazing and selectivity of phytoplankton in coastal waters. Mar Biol 93:581-590

Caffrey JM, Cloern JE, Grenz C (1998) Changes in production and respiration during a spring phytoplankton bloom in San Francisco Bay, California, USA: implications for net ecosystem metabolism. Mar Ecol Prog Ser 172:1-12

Calbet A, Landry MR (2004) Phytoplankton growth, microzooplankton grazing, and carbon cycling in marine systems. Limnol Oceanogr 49:51-57

> Calbet A, Saiz E (2005) The ciliate-copepod link in marine ecosystems. Aquat Microb Ecol 38:157-167

> Dagg MJ, Cowles T, Whitledge T, Smith S, Howe S, Judkins D (1980) Grazing and excretion by zooplankton in the Peru upwelling system during April 1977. Deep-Sea Res 27:43-59

> Dam HG, Peterson WT (1993) Seasonal contrasts in the diel vertical distribution, feeding behavior, and grazing impact of the copepod Temora longicornis in Long Island Sound. J Mar Res 51:561-594

del Giorgio PA, Duarte CM (2002) Total respiration and the organic carbon balance of the open ocean. Nature 420:379-384
Ducklow HW, Dickson ML, Kirchman DL, Steward G, Orchardo J, Marra J, Azam F (2000) Constraining bacterial production, conversion efficiency and respiration in the Ross Sea, Antarctica, January-February, 1997. DeepSea Res II 47:3227-3247

Erga SR, Heimdal BR (1984) Ecological studies on the phytoplankton of Korsfjorden, western Norway. The dynamics of a spring bloom seen in relation to hydrographical conditions and light regime. J Plankton Res 6:67-90

Gauld DT, Raymont UEG (1953) The respiration of some planktonic copepods. II. The effect of temperature. J Mar Biol Assoc UK 41:447-460

Guillard RRL, Ryther JH (1962) Studies of marine planktonic diatoms. I. Cyclotella nana Hustedt and Detonula confervacea Cleve. Can J Microbiol 8:229-239

Hansen B, Verity P, Falkenhaug $T$, Tande KS, Norrbin F (1994) On the trophic fate of Phaeocystis pouchetii (Harriot). Trophic relationships between Phaeocystis and zooplankton: an assessment of methods and size dependence. J Plankton Res 16:487-511

Hansen BW, Hygum BH, Brozek M, Jensen F, Rey C (2000) Food web interactions in a Calanus finmarchicus dominated pelagic ecosystem-a mesocosm study. J Plankton Res 22:569-588

Heimdal BR (1974) Composition and abundance of phytoplankton in the Ullsfjord area, North Norway. Astarte $7: 17-42$

> Hernández-León S, Gómez M (1996) Factors affecting the respiration/ETS ratio in marine zooplankton. J Plankton Res 18:239-255

Hernández-León S, Ikeda T (2005) A global assessment of mesozooplankton respiration in the ocean. J Plankton Res 27:153-158

Hernández-León S, Torres S, Gómez M, Montero I, Almeida C (1999) Biomass and metabolism of zooplankton in the Bransfield Strait (Antarctic Peninsula) during austral spring. Polar Biol 21:214-219

> Hygum BH, Rey C, Hansen BW, Carlotti F (2000) Rearing cohorts of Calanus finmarchicus (Gunnerus) in mesocosms. ICES J Mar Sci 57:1740-1751

- Ianora A, Miralto A (2010) Toxigenic effects of diatoms on grazers, phytoplankton and other microbes: a review. Ecotoxicology 19:493-511

Ikeda T, Torres JJ, Hernández-León S, Geiger SP (2000) Metabolism. In: Harris RP, Wiebe PH, Lenz J, Skjoldal HR, Huntley M (eds) ICES zooplankton methodology manual. Academic Press, San Diego, CA, p 455-532

Ikeda T, Kanno Y, Ozaki K, Shinada A (2001) Metabolic rates of epipelagic marine copepods as a function of body mass and temperature. Mar Biol 139:587-596

- Irigoien X, Head R, Klenke U, Meyer-Harms B and others (1998) A high frequency time series at weathership $M$, Norwegian Sea, during the 1997 spring bloom: feeding of adult female Calanus finmarchicus. Mar Ecol Prog Ser 172:127-137

> Irigoien X, Head RN, Harris RP, Cummings D, Harbour D, Meyer-Harms B (2000a) Feeding selectivity and egg production of Calanus helgolandicus in the English Channel. Limnol Oceanogr 45:44-54

> Irigoien X, Harris RP, Head RN, Harbour D (2000b) The influence of diatom abundance on the egg production rate of Calanus helgolandicus in the English Channel. Limnol Oceanogr 45:1433-1439

Jensen LM, Sand-Jensen K, Marcher S, Hansen M (1990) Plankton community respiration along a nutrient gradi- 
ent in a shallow Danish estuary. Mar Ecol Prog Ser 61:75-85

> Jónasdóttir SH, Gudfinnsson HG, Gislason A, Astthorsson OS (2002) Diet composition and quality for Calanus finmarchicus egg production and hatching success off south-west Iceland. Mar Biol 140:1195-1206

> Jónasdóttir SH, Trung NH, Hansen F (2005) Egg production and hatching success in the calanoid copepods Calanus helgolandicus and Calanus finmarchicus in the North Sea from March to September 2001. J Plankton Res 27: 1239-1259

Jónasdóttir S, Dutz J, Koski M, Yebra L, Jakobsen $\mathrm{HH}_{\text {, }}$ Vidoudez C, Pohnert G, Nejstgaard JC (2011) Extensive cross disciplinary analysis of biological and chemical control of Calanus finmarchicus reproduction during an aldehyde forming diatom bloom in mesocosms. Mar Biol 158:1943-1963

> Keister JE, Peterson WT, Pierce SD (2009) Zooplankton distribution and cross-shelf transfer of carbon in an area of complex mesoscale circulation in the northern California. Deep-Sea Res I 56:212-231

Kemp WM, Boynton WR (2004) Productivity, trophic structure and energy flow in the steady-state ecosystems of Silver Springs, Florida. Ecol Model 178:43-49

Kiørboe T, Mohlemberg F, Hamburger K (1985) Bioenergetics of the planktonic copepod Acartia tonsa: relation between feeding, egg production and respiration, and composition of specific dynamic action. Mar Ecol Prog Ser 26:85-97

Kleppel GS (1993) On the diet of calanoid copepods. Mar Ecol Prog Ser 99:183-195

Koski M (2007) High reproduction of Calanus finmarchicus during a diatom-dominated spring bloom. Mar Biol 151: 1785-1798

Koski M, Wexels-Riser C (2006) Post-bloom feeding of Calanus finmarchicus copepodites: selection for autotrophic vs. heterotrophic prey. Mar Biol Res 2: 109-119

Koski M, Yebra L, Dutz J, Jonasdottir S and others (in press) The effect of egg versus seston quality on hatching success, naupliar metabolism and survival of Calanus finmarchicus in mesocosms dominated by Phaeocystis and diatoms. Mar Biol doi:10.1007/s00227011-1843-z

Köster M, Krause C, Paffenhöfer GA (2008) Time-series measurements of oxygen consumption of copepod nauplii. Mar Ecol Prog Ser 353:157-164

> Lancelot C, Billen G (1984) Activity of heterotrophic bacteria and its coupling to primary production during the spring phytoplankton bloom in the southern bight of the North Sea. Limnol Oceanogr 29:721-730

Lancelot C, Billen G, Veth C, Becquevort S, Mathot S (1991) Modelling carbon cycling through phytoplankton and microbes in the Scotia-Weddell Sea area during sea ice retreat. Mar Chem 35:305-324

> Lee S, Kang YC, Fuhrman JA (1995) Imperfect retention of natural bacterioplankton cells by glass fiber filters. Mar Ecol Prog Ser 119:285-290

Li C, Sun S, Wang R, Wang X (2004) Feeding and respiration rates of a planktonic copepod (Calanus sinicus) over summering in Yellow Sea Cold Bottom Waters. Mar Biol 145:149-157

Lima ID, Olson DB, Doney SC (2002) Intrinsic dynamics and stability properties of size-structured pelagic ecosystem models. J Plankton Res 24:533-556
Marshall S (1973) Respiration and feeding in copepods. Adv Mar Biol 11:57-120

Marshall SM, Orr AP (1958) On the biology of Calanus finmarchicus. X. Seasonal changes in oxygen consumption. J Mar Biol Assoc UK 37:459-472

Mayzaud P, Roche-Mayzaud O, Razouls S (1992) Medium term time acclimation of feeding and digestive enzyme activity in marine copepods: influence of food concentration and copepod species. Mar Ecol Prog Ser 89:197-212

> Nejstgaard JC, Gismervik I, Solberg PT (1997) Feeding and reproduction by Calanus finmarchicus, and microzooplankton grazing during mesocosm blooms of diatoms and the coccolithophore Emiliania huxleyi. Mar Ecol Prog Ser 147:197-217

> Nejstgaard JC, Hygum BH, Naustvoll LJ, Båmstedt U (2001a) Zooplankton growth, diet and reproductive success compared in simultaneous diatom- and flagellatemicrozooplankton-dominated plankton blooms. Mar Ecol Prog Ser 221:77-91

> Nejstgaard JC, Naustvoll LJ, Sazhin A (2001b) Correcting for underestimation of microzooplankton grazing in bottle incubation experiments with mesozooplankton. Mar Ecol Prog Ser 221:59-75

> Nejstgaard JC, Frischer ME, Verity PG, Anderson JT and others (2006) Plankton development and trophic transfer in seawater enclosures with nutrients and Phaeocystis pouchetii added. Mar Ecol Prog Ser 321:99-121

> Painting SJ, Lucas MI, Peterson WT, Brown PC, Hutchings L, Mitchell-Iness BA (1993) Dynamics of bacterioplankton, phytoplankton and mesozooplankton communities during the development of an upwelling plume in the southern Benguela. Mar Ecol Prog Ser 100:35-53

> Pomeroy LR, Sheldon JE, Sheldon WM Jr, Peters F (1995) Limits to growth and respiration of bacterioplankton in the Gulf of Mexico. Mar Ecol Prog Ser 117:259-268

Rivkin RB, Legendre L (2001) Biogenic carbon cycling in the upper ocean: effects of microbial respiration. Science 291:2398-2400

Robinson C (2000) Plankton gross production and respiration in the shallow water hydrothermal systems of Milos, Aegean Sea. J Plankton Res 22:887-906

Robinson C, Widdicombe CE, Zubkov MV, Tarran GA, Miller AEJ, Rees AP (2002a) Plankton community respiration during cocolithophore bloom. Deep-Sea Res II 49:2929-2950

Robinson C, Serret P, Tilstone G, Teira E, Zubkov MV, Rees AP, Woodward EMS (2002b) Plankton respiration in the eastern Atlantic. Deep-Sea Res I 49:787-813

Rosenberg R, Dahl E, Edler L, Fyrberg L and others (1990) Pelagic nutrient and energy transfer during spring in the open and coastal Skagerrak. Mar Ecol Prog Ser 61: 215-231

Rudek J, Cloern JE (1996) Planktonic respiration rates in San Francisco Bay. In: Hollibaugh JT (ed) San Francisco Bay: the ecosystem. AAAS Pacific Division, San Francisco, CA, p 289-304

Sherr EB, Sherr BF, Sigmon CT (1999) Activity of marine bacteria under incubated and in situ conditions. Aquat Microb Ecol 20:213-223

Steele JH (1974) The structure of marine ecosystems. Harvard University Press, Cambridge, MA

Steeman-Nielsen E (1952) The use of radioactive carbon (C14) for measuring organic production in the sea. J Cons Int Explor Mer 18:117-140

Takahashi K, Nagao N, Taguchi S (2002) Respiration of 
adult female Calanus hyperboreus (Copepoda) during spring in the north water Polynya. Polar Biosci 15:45-51

Thor P (2000) Relationship between specific dynamic action and protein deposition in calanoid copepods. J Exp Mar Biol Ecol 245:171-182

Thor P (2002) Specific dynamic action and carbon incorporation in Calanus finmarchicus copepodites and females. J Exp Mar Biol Ecol 272:159-169

Vidal J (1980) Physioecology of zooplankton. I. Effects of phytoplankton concentration, temperature and body size on the growth rate of Calanus pacificus and Pseudocalanus sp. Mar Biol 56:111-134

Vidoudez C, Pohnert G (2008) Growth phase-specific release of polyunsaturated aldehydes by the diatom Skeletonema marinoi. J Plankton Res 30:1305-1313

Vidoudez C, Nejstgaard JC, Jakobsen HH, Pohnert G (2011)

Editorial responsibility: Edward Durbin, Narragansett, Rhode Island, USA
Dynamics of dissolved and particulate polyunsaturated aldehydes in mesocosms inoculated with different densities of the diatom Skeletonema marinoi. Mar Drugs 9:500-513

Warkentin M, Freese HM, Karsten U, Schumann R (2007) New and fast method to quantify respiration rates of bacterial and plankton communities in freshwater ecosystems by using optical oxygen sensor spots. Appl Environ Microbiol 73:6722-6729

Wiborg KF (1954) Investigations on zooplankton in coastal and offshore waters of western and northwestern Norway, with special reference to the copepods. Rep Norweg Fish Invest 11:1-246

Witek Z, Drgas A, Ameryk A, Ochocki S (2001) Production and mineralization of organic matter in the Pomeranian Bay. Bull Sea Fish Inst 154:49-69

Submitted: May 31, 2011; Accepted: December 5, 2011 Proofs received from author(s): March 30, 2012 